\title{
Potret Keislaman Mahasiswa Universitas Al Azhar Indonesia
}

\author{
Abdullah Hakam Shah ${ }^{1 *}$, Nur Hizbullah ${ }^{2}$, M. Risman ${ }^{3}$ \\ ${ }^{1}$ Program Studi Healing \& Counseling, Fakultas Psikologi dan Pendidikan \\ Universitas Al Azhar Indonesia, Jalan Sisingamangaraja, Jakarta, 12110 \\ ${ }^{2}$ Sastra Arab, Fakultas Sastra, \\ Universitas Al Azhar Indonesia, Jalan Sisingamangaraja, Jakarta, 12110 \\ ${ }^{3}$ Staf Pusat Kajian \& Pengembangan Nilai-Nilai Islam (PKPNI), \\ Universitas Al Azhar Indonesia, Jalan Sisingamangaraja, Jakarta, 12110
}

"Penulis untuk Korespondensi: ashilauai@uai.ac.id

\begin{abstract}
Abstrak - Memotret realitas keislaman mahasiswa UAI secara akurat merupakan titik tolak dilakukannya penelitian ini. Diharapkan, potret tersebut bermanfaat dalam merumuskan model kebijakan, regulasi, dan pendekatan yang relevan dan efektif dalam menanamkan nilainilai keislaman di kalangan mahasiswa UAI. Oleh karena itu, penelitian ini berusaha mencover responden dalam prosentase yang relatif besar (sampai dengan $18 \%$ dari populasi) dari seluruh fakultas di UAI, dari angkatan 2008, 2009, dan 2010. Pengambilan sampel menggunakan metode proportional random sampling mengingat jumlah mahasiswa per fakultas yang tidak sama. Penelitian ini menyimpulkan sejumlah poin penting, di antaranya: (1) Realitas keislaman mahasiswa UAI secara umum tergolong sedang, (2) Ada kesenjangan antara aspek akidah, ibadah dan akhlak dalam keislaman mereka. Dalam hal akidah, mereka relatif baik. Namun terlihat penurunan dalam aspek ibadah dan akhlak, (3) Lingkungan tempat mereka tumbuh dan perhatian orang tua berpengaruh signifikan terhadap keislaman mereka.
\end{abstract}

Abstract - The main purpose of this research is to capture the reality of UAI student Islamic life. Hopefully, the output of the research able to formulate regulation, policy, and relevan approaches in assisting Islamic values among UAI student effectively. Therefore, the research trying to cover huge presentage of respondents (reaching 18 percent out of all students) from all faculties in UAI. The respondent qustioned in this polling coming from periode of 2008,2009 and 2010. This polling using proportional random sampling method, that is why the average of every faculty has different percentage. The research concludes some important points; including (1) Islamic life of UAI students relatively classified as moderate, (2) There is also gap among students in term of faith (creed), worship and morality. In term of faith, they are mainly good. But in term of worship and morality the result shows significant decrease, (3) The Background which they were growing up and the parental cares having great influences on how they hold Islamic values.

Keywords - UAI Students, Islamic life of UAI students

\section{PENDAHULUAN}

Salah satu identitas yang melekat kuat pada UUniversitas Al Azhar Indonesia (UAI) adalah identitas keislaman. Sejak berdiri pada tahun 2000, UAI tidak bisa dilepaskan dari sejarah dan citra masjid agung serta Yayasan Pesantren Islam (YPI) Al-Azhar. Identitas ini semakin dipertegas dengan dijadikannya nilai-nilai keislaman (Islamic values) sebagai elemen pertama dari tujuh elemen dasar UAI.

Fakta tersebut merupakan salah satu pertimbangan penting para orangtua untuk memasukkan anakanak mereka kuliah di UAI. Sebab mereka berharap selain kualitas yang mumpuni di bidang keilmuannya, dengan kuliah di UAI anak-anak mereka tidak akan tercerabut dari identitas dan 
nilai-nilai keislaman. Hal ini menjawab banyak kekhawatiran seputar menipisnya perhatian terhadap penanaman etika dan nilai-nilai keagamaan di sebagian besar perguruan tinggi umum (PTU) dewasa ini.

Sekalipun secara umum mahasiswa UAI berasal dari kalangan masyarakat muslim perkotaan, namun pada kenyataannya realitas keislaman mereka tidaklah homogen. Mulai dari tingkat pemahaman, tingkat pengamalan, maupun cara mereka menyikapi kasus-kasus di sekeliling mereka berdasarkan nilai dan ajaran Islam.

Usia mahasiswa UAI yang mayoritas muda (18 sampai 23 tahun) yang sering disebut masa pancaroba dengan ciri utama belum terbangunnya kematangan berpikir, keseimbangan kepribadian, dan kestabilan keberagamaan, juga tidak menjamin realitas keislaman mereka yang seragam. Andre Charron memang pernah memaparkan hasil penelitian bahwa di kalangan muda ada suatu pola yang sama, yaitu "penjauhan progresif" terhadap agama (D. Hendropuspito, 1983). Akan tetapi, penelitian yang dilakukan di kalangan muda (non muslim) Kanada itu terlalu banyak mengandung celah kritik dan kelemahan argumen untuk dijadikan pijakan dalam membaca keislaman mahasiswa UAI.

Berdasarkan paparan di atas, perlu diteliti bagaimana realitas keislaman mahasiswa UAI, serta faktor-faktor yang mempengaruhinya. Ini sangat penting sebagai basis informasi dalam rangkaian upaya mengukuhkan nilai-nilai keislaman di lingkungan UAI. Selain itu, hasil penelitian ini bisa menjadi acuan dalam merumuskan model kebijakan, regulasi, dan pendekatan yang relevan dan efektif dalam menanamkan nilai-nilai keislaman di kalangan mahasiswa UAI.

\subsection{Permasalahan}

Penelitian ini bermaksud menelaah poin-poin sebagai berikut:

1) Bagaimanakah realitas keislaman mahasiswa UAI?

2) Sejauhmanakah signifikansi pengaruh faktorfaktor jender, lingkungan tempat tumbuh, dan tempat tinggal terhadap keislaman mereka?

\subsection{Tujuan dan Manfaat Penelitian}

Penelitian ini bertujuan mengetahui dan mendeskripsikan realitas keislaman mahasiswa UAI.

Dengan demikian, penelitian ini diharapkan bermanfaat memberikan informasi tentang realitas keislaman mahasiswa UAI:

1) Sebagai masukan pertimbangan bagi civitas akademika UAI dalam mengukuhkan nilai-nilai keislaman (Islamic values) di lingkungan UAI.

2) Sebagai masukan evaluasi bagi para dosen pengampu mata kuliah pendidikan agama Islam maupun mata kuliah yang berkaitan dengan pembentukan karakter mahasiswa UAI dalam mengemas perkuliahan dan merumuskan pendekatan yang lebih efektif.

\section{KERANGKA TEORI/TINJAUAN PUSTAKA}

\subsection{Pengertian Potret}

Dalam Kamus Besar Bahasa Indonesia (KBBI), potret didefinisikan sebagai gambar yang dibuat dengan kamera, foto; gambaran dalam bentuk paparan. Dalam konteks definisi tersebut, potret yang dimaksud penelitian ini adalah pemetaan dan gambaran realitas keislaman yang wujud dalam diri dan keseharian mahasiswa UAI.

\subsection{Pengertian Keislaman}

John L. Esposito (2010) menyatakan, "While we commonly speak of 'Islam', in fact many Islams or interpretations of Islam exist. The images and realities of Islam and of muslims are multiple and diverse..." Tesa Esposito ini juga dapat ditemukan dalam realitas keislaman mahasiswa UAI. Dengan latar kultur keluarga, lingkungan, serta pendidikan yang mereka alami sebelum menjadi mahasiswa UAI, keragaman keislaman tersebut menjadi sangat wajar dan niscaya.

Dalam sebuah hadits shahih yang diriwayatkan Muslim dari Umar bin Khattab RA., Rasulullah SAW. bersabda bahwa risalah yang diembannya terdiri dari tiga unsur pokok, yaitu: akidah (iman), ibadah (Islam), dan akhlak (ihsan). Ketiga unsur pokok inilah yang menjadi pilar keislaman seseorang. 
Tiga aspek keislaman seseorang (akidah, ibadah dan akhlak) tersebut merupakan satu kesatuan yang tidak terpisahkan (Kaelany HD:2000). Akidah yang kokoh akan mendorongnya untuk taat beribadah, dan keistiqamahannya beribadah akan berimplikasi pada perilaku dan akhlak sehari-hari.

\subsection{Tinjauan tentang Iman/Akidah}

Iman, dalam bahasa Arab, berasal dari kata kerja amina-ya'manu yang berarti percaya. Iman menunjuk sikap batin yang terpusat di hati. Tetapi tidak hanya berhenti dengan percaya, melainkan mendorong orang yang memilikinya untuk melakukan ibadah dan amal yang terpuji. AlGhazali mensyaratkan tiga wujud iman; pembenaran di dalam hati, pengikraran dengan lidah, serta pengimplementasian dengan perbuatan (al-Iqtishaad fi al-I'tiqaad:66). Dalam terminologi al-Qur'an, iman juga disebut dengan akidah.

Hal-hal yang wajib diimani oleh setiap muslim ada enam perkara. 1) Iman kepada Allah, 2) Iman kepada malaikat-malaikatNya, 3) Iman kepada kitab-kitabNya, 4) Iman kepada Rasul-rasulNya, 5) Iman kepada Hari Akhir, 6) Iman kepada ketentuan Allah.

Walaupun iman merupakan hal yang abstrak (tidak bisa diukur secara kasat mata), namun orang yang memiliki iman dapat diketahui dengan memperhatikan prilaku dan pandangan hidupnya. Misalnya, menyadari bahwa Allah Maha melihat segala perbuatannya, tidak meragukan syariat Allah, mempraktikkan keteladan Rasulullah, yakin akan akhirat, dan berintrospeksi diri seperti dengan mengingat kematian.

\subsection{Tinjauan tentang Islam/Ibadah}

Islam, dalam bahasa Arab, berasal dari kata kerja aslama-yuslimu yang berarti penyerahan kepada Allah SWT. Penyerahan ini harus berwujud kepatuhan dan ketaatan untuk melaksanakan segala perintahNya, serta menjauhi apapun laranganNya. Pengakuan keislaman seseorang tidak valid selama tidak melakukan perintah Allah dan menjauhi laranganNya.

Hal-hal yang menjadi pilar Islam terejewantah dalam lima perkara. 1) Mengucapkan dua kalimat syahadat, 2) Mendirikan shalat, 3) Menjalankan puasa Ramadhan, 4) Menunaikan zakat, dan 5) Pergi haji ke Baitullah bagi yang mampu.
Lima perkara tersebut yang menjadi indikator utama ibadah seorang muslim. Dari sisi pengamalannya, kelima perkara tersebut bisa diklasifikasikan ke dalam ibadah lisan dan hati (mengucapkan syahadat), ibadah fisik (shalat dan puasa), ibadah harta (zakat), dan ibadah fisik-harta (haji). Sementara dari tingkat pewajibannya, keempat perkara yang terakhir bisa dibagi ke dalam wajib dan sunah. Misalnya, ada shalat wajib dan shalat sunah, puasa wajib dan puasa sunah, zakat wajib dan sedekah, serta haji wajib dan haji sunah.

\subsection{Tinjauan tentang Ihsan/Akhlak}

Akhlak, dalam bahasa Arab, merupakan bentuk jama' dari khuluqun yang berarti budi pekerti. Menurut Ibnu Miskawaih, akhlak adalah keadaan jiwa seseorang yang mendorongnya untuk melakukan perbuatan-perbuatan tanpa melalui pertimbangan pikiran terlebih dahulu (Thohir Luth, 2007:115). Akhlak secara substansial merupakan sifat hati seseorang yang tercermin dalam prilaku.

Secara garis besar, akhlak dibagi menjadi akhlak karimah (budi pekerti yang luhur) dan akhlak madzmumah (budi pekerti yang buruk). Keduanya terimplementasi dalam prilaku seseorang kepada Allah SWT, kepada orang lain, dan kepada dirinya sendiri. Akhlak seseorang kepada Allah SWT. terimplementasi dominan dalam akidah dan ibadahnya. Sementara akhlak kepada diri sendiri dan orang lain terlihat dari gaya hidup dan pola interaksinya sehari-hari.

\section{METODOLOGI PENELITIAN}

\subsection{Pendekatan Penelitian}

Penelitian ini menggunakan pendekatan kuantitatifdeskriptif, yaitu penelitian yang berpretensi menjelaskan, meringkaskan berbagai kondisi, berbagai situasi, atau berbagai variabel di masyarakat yang menjadi objek penelitian itu berdasarkan apa yang terjadi. Kemudian mengangkat ke permukaan karakter atau gambaran tentang kondisi, situasi, ataupun variabel tersebut (Burhan Bungin, 2005).

\subsection{Subjek penelitian.}

1) Populasi Penelitian Populasi dalam penelitian ini adalah mahasiswa UAI dari angkatan 2008, 2009, dan 2010. 
2) Sampel Penelitian

Mahasiswa UAI terdiri dari 6 fakultas, maka agar diperoleh sampel yang cukup representatif digunakan teknik pengambilan sampel secara acak dan proporsional atau proportional random sampling.

Teknik pengambilan secara proporsional ini dipilih karena masing-masing fakultas mempunyai jumlah mahasiswa yang berbeda. Selanjutnya pengambilan sampel ditentukan secara random. Hal ini disebabkan metode random memberi kemungkinan pada semua mahasiswa sebagai subyek dalam populasi berkesempatan menjadi sampel penelitian (Sutrisno Hadi, 1990:203).

Dalam penentuan sampel masing-masing fakultas/prodi dapat dijabarkan pada tabel 1 .

\subsection{Teknik Pengumpulan Data}

Pengumpulan data merupakan cara-cara yang dapat dipergunakan oleh peneliti untuk mengumpulkan data-data. Macam-macam metode atau teknik pengumpulan data antara lain: angket (kuesioner), wawancara (interview), pengamatan (observasi), ujian (Tes) dan dokumentasi”. (Suharsimi Arikunto, 1993:121122)

Metode yang digunakan dalam penelitian ini adalah metode angket atau kuesioner. Tepatnya, angket tertutup, langsung dan berbentuk skala bertingkat. Menurut Suharsimi Arikunto (1991:124), angket tertutup adalah angket yang telah disediakan jawabannya, sehingga responden tinggal memilih salah satu dari jawaban-jawaban tersebut. Dan angket langsung adalah angket meminta responden untuk menjawab langsung tentang dirinya. Sementara angket berbentuk skala bertingkat adalah angket yang berisi itemitem yang diikuti kolom-kolom yang menunjukkan tingkat-tingkat, misalnya mulai dari selalu, sering, jarang, dan tidak pernah

Alasan pemilihan metode angket dalam penelitian ini didasarkan atas asumsi yang dikemukakan Sutrisno Hadi bahwa:

1) Subyek adalah orang yang paling tahu tentang dirinya
2) Apa yang dinyatakan subyek kepada peneliti adalah benar dan dapat dipercaya.

3) Interprestasi subyek tentang pertanyaan yang diajukan adalah sama dengan apa yang dimaksud peneliti (Sutrisno Hadi, 1990:157)

Namun metode pengumpulan data dengan angket juga memiliki beberapa kelemahan sebagaimana dikemukakan oleh Suharsini Arikunto, di antaranya:

1) Responden sering tidak teliti dalam menjawab, sehingga ada pertanyaan yang terlewati/tidak dijawab, padahal sukar dikembalikan padanya.

2) Sering sukar dicari validitasnya.

3) Walaupun dibuat secara anonim kadangkadang responden memberikan jawaban yang tidak jujur.

4) Seringkali tidak kembali terutama jika dikirim lewat pos.

5) Waktu pengembalian tidak sama-sama dan bahkan ada yang terlalu lama sehingga terlambat. (1992:126)

Untuk mengatasi beberapa kelemahan tersebut, terutama yang berkaitan dengan waktu pengumpulan dan ketelitian memberikan jawaban, peneliti menerapkan kiat-kiat sebagai berikut:

1) Memberikan petunjuk dalam angket yang jelas.

2) Mengadakan pendekatan yang manusiawi dalam meminta responden untuk mengisi angket.

3) Memberikan keleluasaan seperlunya sehingga angket tidak dikerjakan dengan terlalu tergesa-gesa dan agar jawaban dapat diberikan sesuai dengan yang sebenarnya.

4) Mengadakan pendampingan dan penjelasan jika pada pelaksanaannya responden mengalami kesulitan, dan kalau ada hal-hal yang kurang jelas.

Dengan demikian, maka diharapkan dari angket tersebut dapat diperoleh data yang benar-benar telah menggambarkan keadaan yang sebenarnya dari responden yang diteliti. 
Tabel 1. Proportional Random Sampling per Fakultas/Prodi.

\begin{tabular}{|c|c|c|c|c|c|c|}
\hline No & Fakultas/Program Studi & 2008 & 2009 & 2010 & Jumlah & Jml Angket \\
\hline \multicolumn{7}{|c|}{ Fakultas Sains dan Teknologi (FST) } \\
\hline 1 & Teknik Industri & 24 & 21 & 35 & 80 & 16 \\
\hline 2 & Teknik Informatika & 35 & 22 & 37 & 94 & 19 \\
\hline 3 & Teknik Elektro & 19 & 9 & 18 & 46 & 10 \\
\hline 4 & Biologi (Bioteknologi) & 24 & 24 & 27 & 75 & 15 \\
\hline \multicolumn{7}{|c|}{ Fakultas Ekonomi (FE) } \\
\hline 5 & Manajemen & 64 & 63 & 49 & 176 & 35 \\
\hline 6 & Akuntansi & 34 & 46 & 34 & 114 & 24 \\
\hline \multicolumn{7}{|c|}{ Fakultas Sastra (FS) } \\
\hline 7 & Sastra Arab & 20 & 20 & 24 & 64 & 14 \\
\hline 8 & Sastra Cina & 12 & 18 & 8 & 38 & 9 \\
\hline 9 & Sastra Inggris & 29 & 36 & 27 & 92 & 19 \\
\hline 10 & Sastra Jepang & 17 & 19 & 17 & 53 & 11 \\
\hline \multicolumn{7}{|c|}{ Fakultas Psikologi dan Pendidikan (FPsP) } \\
\hline 11 & Dakwah (Healing \& Konseling) & 13 & 12 & 4 & 29 & 7 \\
\hline 12 & Tarbiyah PAUD & 27 & 38 & 34 & 99 & 21 \\
\hline 13 & Psikologi & 42 & 55 & 57 & 154 & 31 \\
\hline \multicolumn{7}{|c|}{ Fakultas Hukum (FH) } \\
\hline 14 & $\begin{array}{l}\text { Ilmu Hukum (Hukum Ekonomi \& } \\
\text { Teknologi) }\end{array}$ & 46 & 41 & 45 & 132 & 26 \\
\hline \multicolumn{7}{|c|}{ Fakultas Ilmu Sosial dan Ilmu Politik (FISIP) } \\
\hline 15 & Ilmu Hubungan Internasional & 65 & 78 & 83 & 226 & 46 \\
\hline 16 & Ilmu Komunikasi & 150 & 181 & 151 & 482 & 97 \\
\hline
\end{tabular}

\subsection{Instrumen Penelitian}

Prosedur yang ditempuh dalam pengadaan instrumen yang baik secara berturut-turut adalah perencanaan, penulisan butir item, penyuntingan, uji coba, penganalisaan hasil (Suharsini Arikunto, 1989:134-135). Berdasarkan pendapat tersebut, langkah-langkah pengadaan instrumen yang ditempuh dalam penelitian ini adalah:

1) Perencanaan dan penulisan butir pernyataan.

Langkah yang dilakukan dalam tahap ini adalah mendefinisikan konsep yang hendak diukur dan menentukan indikator-indikator untuk dijabarkan menjadi butir item. Konsep yang digunakan sebagai dasar instrumen penelitian ini adalah sabda Rasulullah SAW. bahwa risalah yang diembannya terdiri dari tiga unsur pokok, yaitu: Akidah (Iman), Ibadah (Islam), dan Akhlak (Ihsan). (HR. Muslim, dari Umar bin Khattab RA.).

Adapun penetapan skor untuk angket ini dibagi dalam dua bagian; bagian favorable dan bagian unfavourable. Untuk bagian favorable, alternatif A (selalu) dengan skor 4, B (sering) dengan skor 3, C (jarang) dengan skor 2, dan D (tidak pernah) dengan skor 1. Sementara bagian unfavourable menggunakan penghitungan skor sebaliknya; A dengan skor 1, B dengan skor 2, $\mathrm{C}$ dengan skor 3, dan D dengan skor 4 .
2) Penyuntingan

Penyuntingan yang dimaksud meliputi melengkapi instrumen dengan kata pengantar, petunjuk pengisian, ucapan terima kasih, penyediaan lembar jawaban.

3) Uji Coba Instrumen

Uji coba instrumen dikenakan bagi mahasiswa yang nantinya bukan menjadi sampel tetapi masih merupakan satu populasi. Untuk melakukan uji coba instrumen biasanya dengan jumlah responden 30-50 orang sudah mencukupi karena dengan jumlah minimal 30 orang ini maka distribusi skor akan mendekati kurve normal. Dalam hal ini, peneliti mengambil 30 mahasiswa untuk dikenai uji coba. Dalam uji coba ini meliputi:

a. Uji Coba Validitas Instrumen

Menurut Suharsini Arikunto (1991:136) validitas adalah "Suatu ukuran yang menunjukkan tingkat kevalidan atau kesahihan suatu instrumen". Tinggi rendahnya validitas instrumen menunjukkan sejauh mana data yang terkumpul tidak menyimpang dari gambaran tentang variabel yang dimaksud. Berkaitan dengan validitas ini, Sutrisno Hadi mengemukakan jenis-jenis validitas, yaitu: face validity, Logical validity, factorial validity, Content validity dan empirical validity. Dalam penelitian ini semua angket menggunakan Construct 
Validity atau Logical Validity, karena buturbutir dalam instrumen dikembangkan berdasarkan konstruksi teoritik.

Untuk mengetahui ketepatan data dilakukan tehnik uji validitas internal. Uji validitas internal dilakukan melalui uji validitas butir. Untuk menguji validitas butir digunakan tehnik atau rumus korelasi product moment dari Karl Pearson. Rumus korelasi product yang dimaksud adalah:

$$
\mathrm{IXy}=\frac{\mathrm{NEXY}-(\mathrm{LX})(\mathrm{LI})}{\sqrt{\left\{(\mathrm{NLX})^{2}-(\mathrm{LX})^{2}\right\}\left\{(\mathrm{NLY})^{2}-(\mathrm{LI})^{2}\right\}}}
$$

Keterangan:

Rxy : Koefisien korelasi antara X dengan Y

$\sum X \quad$ : Jumlah skor tiap butir

$\sum \mathrm{Y}:$ Jumlah skor total

$\sum \mathrm{XY}$ : Jumlah hasil kali skor $\mathrm{X}$ dengan skor $\mathrm{Y}$

$\sum \mathrm{X}^{2}$ : Jumlah $\mathrm{X}$

$\sum \mathrm{Y}^{2}$ : Jumlah $\mathrm{Y}$

$\mathrm{N}$ : Banyaknya subyek

(Arikunto, 1993:138)

Hasil perhitungan dengan korelasi tersebut masih dikontrol atau dicek dengan korelasi Part Whole untuk menghindari Overestimate, sehingga diperoleh harga rpq atau rbt. Adapun rumusnya:

$$
\Gamma \mathrm{pq}=\frac{\Gamma p q: \mathrm{SDt}-\mathrm{SDp}}{\left\{\left(\mathrm{SDt}^{2}+\mathrm{SDp}^{2}\right)(\Gamma t p: \mathrm{SDt}-\mathrm{SDp})\right\}}
$$

Keterangan :

Rpq : Koefisien korelasi bagian total

Rtp : Koefisien korelasi product moment

SDp : Standar deviasi total

SDt : Standar deviasi sub total

(Sutrisno Hadi, 1987:290)

b. Uji Reliabilitas Instrumen

Uji reliabilitas dalam penelitian ini menggunakan rumus alpha, karena skor item bukan nol atau satu. Sebagaimana penjelasan Suharsini Arikunto bahwa rumus alpha digunakan untuk mencari reabilitas instrumen yang skornya bukan nol atau satu, misalnya angket atau soal bentuk uraian (196:190). Rumus alpha tersebut adalah:

$$
\mathrm{rii}=\left(\frac{k}{k-1}\right)\left(1-\frac{\sum \mathscr{B}^{2}}{\dot{\alpha}^{2}}\right)
$$

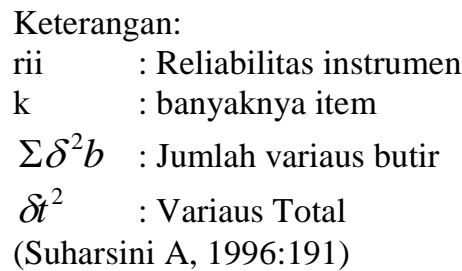

Hasil riil yang telah diperoleh dikonsultasikan melalui Standart Errar Measurement (SEM). Adapun rumus SEM adalah sebagai berikut:

$$
\text { SEmeas }=\mathrm{SD} \sqrt{1-r i i}
$$

Keterangan :

SEM : Standart Eraar of Measurement

SD : : Standart Deviasi

rii : Reliabilitas Instrumen

(Gilbert Sax, 1980:274)

Sedangkan standar deviasi (SD) dapat dicari dengan rumus berikut :

$$
\mathrm{SD}=\sqrt{\frac{\sum \mathrm{X}^{2}}{\mathrm{~N}}-\left[\frac{\sum \mathrm{X}}{\mathrm{N}}\right]^{2}}
$$

Keterangan :

SD : Standart deviasi

$\Sigma \mathrm{X}^{2} \quad$ : Jumlah kuadrat deviasi skor dari mean $\mathrm{N} \quad$ : Jumlah individu

(Sutrisno Hadi, 1993:50)

Hasil perhitungan dengan SEM ini kemudian dikonsultasikan dengan SD, dengan kriteria bahwa instrumen itu reliabel apabila harga SEM kurang dari $1 / 2$ SD, dan sebaliknya jika harga SEM lebih dari 1 12 SD maka instrumen itu tidak reliabel.

\subsection{Teknik Pengolahan dan Analisis Data}

Data yang dikumpulkan dari angket kemudian diolah dengan teknik statistik deskriptif. Data temuan penelitian berupa angka-angka dan persentase dianalisis dan diinterpretasikan lalu dideskripsikan secara naratif.

\section{HASIL DAN PEMBAHASAN}

Dari empat ratus kuesioner yang disebar, kuesioner yang kembali sampai dengan tanggal 20 November 2011 sebanyak 356. Ini berarti secara rata-rata hanya $18 \%$ dari jumlah populasi, dari target responden semula sebanyak $20 \%$. Itupun tidak merata di semua fakultas; FST, FE, FS, FPsP, dan FH terpenuhi target $20 \%$ dari populasi. Sementara FISIP hanya $13 \%$. 


\subsection{Deskripsi Potret Keislaman Secara Umum}

Setelah dilakukan pengukuran dengan SPSS, hasil penelitian potret keislaman mahasiswa UAI secara umum menunjukkan nilai-nilai rata-ratanya adalah: 3,15 dengan simpangan baku 0,28. Dari ketiga aspek keislaman (akidah, ibadah dan akhlak), yang paling baik adalah aspek akidah mereka dengan nilai rata-rata 3,55 . Aspek akhlak rata-ratanya adalah 3,09. Sementara aspek ibadah mereka tergolong rendah dengan rata-rata 2,8 (tabel 2).

Sedangkan secara kategoris, dengan menggunakan $\mathrm{Z}$ skor, ditemukan $14,6 \%$ responden keislaman mereka tergolong tinggi, $66 \%$ responden tergolong sedang, dan 19,4\% masuk kategori rendah (tabel 3).

\subsection{Deskripsi Potret Keislaman Berdasarkan Fakultas.}

Sementara berdasarkan fakultas, potret keislaman responden dapat dilihat dari meannya secara berurutan sebagai berikut (tabel 4 dan 5):

Fakultas Psikologi dan Pendidikan : 3,22

Fakultas Sains dan Teknologi $\quad: 3,21$

Fakultas Sastra $\quad: 3,20$

Fakultas Ekonomi : 3,19

Fakultas Ilmu Sosial dan Ilmu Politik : 3,15

Fakultas Hukum $\quad: 3,00$

Hasil ini menunjukkan bahwa keislaman mahasiswa Fakultas Psikologi dan Pendidikan (FPsP) lebik baik dari teman-teman mereka yang ada di Fakultas Sains dan Teknologi (FST), Fakultas Sastra (FS), Fakultas Ekonomi (FE), Fakultas Ilmu Sosial dan Politik (FISIP), dan Fakultas Hukum (FH). Sementara mahasiswa FH terlihat keislaman mereka kurang dibanding yang lain.

Namun setelah dilakukan uji Anova, dapat disimpulkan tidak ada perbedaan signifikan tingkat keislaman responden berdasarkan Fakultas. Sebab ditemukan $\mathrm{P}$ valuenya adalah 0,064 > 0,05 (tabel 5), berarti H0 diterima.
Tabel 2. Deskripsi Potret Keislaman Secara Umum

\begin{tabular}{|l|r|r|r|r|}
\hline & Total & Akidah & Ibadah & Akhlak \\
\hline N Valid & 356 & 356 & 356 & 356 \\
$\quad$ Missing & 0 & 0 & 0 & 0 \\
Mean & 3.1502 & 3.5531 & 2.8011 & 3.0948 \\
Median & 3.1900 & 3.5700 & 2.8600 & 3.1400 \\
Mode & 3.19 & 3.71 & 2.71 & 3.00 \\
Std. & .28090 & .28965 & .39170 & .36944 \\
Deviation & & 1.43 & 2.29 & 2.00 \\
Range & 1.48 & 2.57 & 1.57 & 2.00 \\
Minimum & 2.38 & 4.00 & 3.86 & 4.00 \\
Maximum & 3.86 & &
\end{tabular}

Tabel 3. Deskripsi Potret Keislaman Secara Umum menggunakan Z skor

\begin{tabular}{|l|r|r|r|r|}
\hline & $\begin{array}{c}\text { Freq } \\
\text { uency }\end{array}$ & \multicolumn{1}{c|}{$\begin{array}{c}\text { Per } \\
\text { cent }\end{array}$} & $\begin{array}{c}\text { Valid } \\
\text { Percent }\end{array}$ & $\begin{array}{c}\text { Cumu } \\
\text { lative } \\
\text { Percent }\end{array}$ \\
\hline Valid Tinggi & 52 & 14.6 & 14.6 & 14.6 \\
Sedang & 235 & 65.8 & 66.0 & 80.6 \\
$\quad \begin{array}{r}\text { Rendah } \\
\text { Total }\end{array}$ & 69 & 19.3 & 19.4 & 100.0 \\
$\begin{array}{l}\text { Missing } \\
\text { System }\end{array}$ & 1 & .3 & 100.0 & \\
Total & 356 & 100.0 & & \\
\hline
\end{tabular}

Tabel 4. Deskripsi Potret Keislaman Berdasarkan Fakultas dilihat dari Meannya

\begin{tabular}{|l|c|c|c|c|c|c|}
\hline & N & Mean & $\begin{array}{c}\text { Std. } \\
\text { Devia- } \\
\text { tion }\end{array}$ & $\begin{array}{c}\text { Std. } \\
\text { Error }\end{array}$ & Min & Max \\
\hline FST & 60 & 3.2092 & .24465 & .03158 & 2.76 & 3.81 \\
FS & 53 & 3.2009 & .28246 & .03880 & 2.57 & 3.86 \\
FPsP & 59 & 3.2158 & .27723 & .03609 & 2.71 & 3.81 \\
FH & 26 & 3.0019 & .23607 & .04630 & 2.57 & 3.48 \\
FE & 59 & 3.1863 & .27389 & .03566 & 2.62 & 3.71 \\
FISIP & 99 & 3.0656 & .28878 & .02902 & 2.38 & 3.67 \\
Total & 356 & 3.1502 & .28090 & .01489 & 2.38 & 3.86 \\
\hline
\end{tabular}

Tabel 5. Homogeneous Subset Potret Keislaman Berdasarkan Fakultas

\begin{tabular}{|l|r|r|r|}
\hline \multirow{2}{*}{ Fakultas } & \multirow{2}{*}{ N } & \multicolumn{2}{|c|}{ Subset for alpha $=\mathbf{0 , 0 5}$} \\
\cline { 3 - 4 } & & \multicolumn{1}{|c|}{$\mathbf{1}$} & \multicolumn{1}{c|}{} \\
\hline FH & 26 & 3.0019 & - \\
FISIP & 99 & 3.0656 & 3.0656 \\
FE & 59 & - & 3.1863 \\
FS & 53 & - & 3.2009 \\
FST & 60 & - & 3.2092 \\
FPsP & 59 & - & 3.2158 \\
Sig. & - & .848 & .064 \\
\hline
\end{tabular}




\subsection{Deskripsi Potret Keislaman Berdasarkan Jender.}

Setelah melihat realitas keislaman responden secara umum dan berdasarkan fakultas masing-masing, maka penelitian ini hendak memaparkan pula realitas keislaman mereka berdasarkan jenis kelaminnya. Dengan menggunakan independent sample $T$ test, pengujian ini menggunakan uji dua sisi dengan tingkat signifikansi $a=5 \%$ atau 0,05 .

Kriteria pengujian berdasar probabilitas:

Ho diterima jika $\mathrm{P}$ value $>0,05$

Ho ditolak jika $\mathrm{P}$ value $<0,05$

Berdasarkan perhitungan, diperoleh bahwa t hitung $=-0,148$ dengan signifikansi 0,883 . P value 0,883 $>0,05$ maka ho diterima. Ini berarti tidak terdapat perbedaan yang signifikan dalam potret keislaman responden yang laki-laki dan perempuan.

\subsection{Deskripsi Potret Keislaman Berdasarkan Tempat Tinggal Sekarang.}

Selanjutnya, penelitian ini hendak melihat realitas keislaman responden berdasarkan tempat tinggal mereka. Sebanyak 324 responden (91\%) tinggal di rumah (bersama orang tua), 24 responden (7\%) kost, dan 8 responden (2\%) tinggal di asrama.

Setelah dilakukan pengujian Anova, dapat dipaparkan responden yang tinggal di asrama keislaman mereka paling baik dengan nilai rata-rata 3,35 ; berikutnya yang kost dengan nilai rata-rata 3,2 ; dan responden yang tinggal di rumah justru paling rendah dibanding dua yang lain dengan nilai rata-rata 3,1 (tabel 8 ).

Tabel 6. Group Statistics

\begin{tabular}{|ll|c|c|r|r|}
\hline \multicolumn{1}{|c|}{ Gender } & N & Mean & $\begin{array}{c}\text { Std. } \\
\text { Deviation }\end{array}$ & $\begin{array}{c}\text { Std. Error } \\
\text { Mean }\end{array}$ \\
\hline Total & Perem-puan & 255 & 3.1488 & .28147 & .01763 \\
& Laki-laki & 101 & 3.1537 & .28081 & .02794 \\
Akidah & Perem-puan & 255 & 3.5385 & .29224 & .01830 \\
& Laki-laki & 101 & 3.5900 & .28105 & .02797 \\
Ibadah & Perem-puan & 255 & 2.8125 & .39910 & .02499 \\
& Laki-laki & 101 & 2.7722 & .37274 & .03709 \\
Akhlak & Perem-puan & 255 & 3.0936 & .36678 & .02297 \\
& Laki-laki & 101 & 3.0978 & .37790 & .03760 \\
\hline
\end{tabular}

Tabel 7. Independent Sample Test

\begin{tabular}{|ll|r|r|r|r|r|r|r|}
\hline \multicolumn{1}{|c|}{} & \multicolumn{2}{|c|}{$\begin{array}{l}\text { Levene's Test } \\
\text { for Equality } \\
\text { of Variances }\end{array}$} & \multicolumn{2}{|c|}{ t-test for Equality of Means } \\
\cline { 3 - 9 } & \multicolumn{1}{|c|}{ F } & \multicolumn{1}{|c|}{ Sig. } & \multicolumn{1}{|c|}{ T } & \multicolumn{1}{|c|}{ Df } & $\begin{array}{c}\text { Sig. } \\
\text { (2-tailed) }\end{array}$ & $\begin{array}{c}\text { Mean } \\
\text { Difference }\end{array}$ & $\begin{array}{l}\text { Std. Error } \\
\text { Difference }\end{array}$ \\
\hline Total & Equal variances assumed & .208 & .649 & -.148 & 354 & .883 & -.00488 & .03307 \\
& Equal variances not assumed & - & - & -.148 & 183.955 & .883 & -.00488 & .03304 \\
Akidah & Equal variances assumed & .113 & .737 & -1.515 & 354 & .131 & -.05149 & .03399 \\
& Equal variances not assumed & - & - & -1.541 & 190.250 & .125 & -.05149 & .03342 \\
Ibadah & Equal variances assumed & .445 & .505 & .876 & 354 & .381 & .04037 & .04607 \\
& Equal variances not assumed & - & - & .903 & 195.561 & .368 & .04037 & .04472 \\
Akhlak & Equal variances assumed & .002 & .960 & -.097 & 354 & .923 & -.00421 & .04350 \\
& Equal variances not assumed & - & - & -.096 & 178.745 & .924 & -.00421 & .04406 \\
\hline
\end{tabular}


Tabel 8. Homogenous Subset Potret Keislaman Berdasarkan Tempat Tinggal Sekarang

\begin{tabular}{|l|r|r|}
\hline \multirow{2}{*}{ Lingkungan } & \multirow{2}{*}{$\mathrm{N}$} & \multicolumn{2}{|c|}{ Subset for alpha $=0.05$} \\
\cline { 3 - 3 } & & 1 \\
\hline Rumah & 324 & 3.1411 \\
Kost & 24 & 3.2037 \\
Asrama & 8 & 3.3562 \\
Sig. & - & .059 \\
\hline
\end{tabular}

Namun secara umum, perbedaan tingkat keislaman antara yang tinggal di asrama, kost, dan di rumah (bersama orang tua) tidak terlalu signifikan karena terlihat $\mathrm{P}$ valuenya $>0,05$. Khususnya terkait aspek akidah dan akhlak. Akan tetapi dalam aspek ibadah dengan $\mathrm{P}$ value $0,023<0,05$ terdapat perbedaan yang signifikan (tabel 9).

\subsection{Deskripsi Potret Keislaman Berdasarkan Tempat Tumbuh}

Dari data responden yang terhimpun dalam penelitian ini, diketahui 332 (93\%) responden tumbuh di lingkungan perkotaan. Sementara 24 (7\%) responden sisanya tumbuh di lingkungan pedesaan. Responden yang tumbuh di lingkungan pedesaan keislaman mereka lebih baik dari yang tumbuh di lingkungan perkotaan (tabel 10).

Dan setelah diuji dengan menggunakan independent sample $T$ test, melalui uji dua sisi dengan tingkat signifikansi $a=5 \%$ atau 0,05 , terlihat dalam tabel 11 , diperoleh $\mathrm{P}$ value $0,04<$ 0,05, berarti H0 ditolak. Maknanya, ada perbedaan signifikan keislaman responden yang tumbuh di pedesaan dibanding mereka yang tumbuh di perkotaan

Tabel 9. Anova

\begin{tabular}{|ll|r|r|r|r|r|}
\hline & $\begin{array}{c}\text { Sum of } \\
\text { Squares }\end{array}$ & Df & $\begin{array}{c}\text { Mean } \\
\text { Square }\end{array}$ & \multicolumn{1}{c|}{ F } & \multicolumn{1}{c|}{ Sig. } \\
\hline Total & Between Groups & .435 & 2 & .218 & 2.786 & .063 \\
& Within Groups & 27.576 & 353 & .078 & - & - \\
& Total & 28.011 & 355 & - & - & - \\
Akidah & Between Groups & .164 & 2 & .082 & .977 & .378 \\
& Within Groups & 29.619 & 353 & .084 & - & - \\
& Total & 29.783 & 355 & - & - & - \\
Ibadah & 1.150 & 2 & .575 & 3.806 & .023 \\
Between Groups & 53.319 & 353 & .151 & - & - \\
Within Groups & 54.468 & 355 & - & - & - \\
Total & .255 & 2 & .127 & .932 & .395 \\
Akhlak & Between Groups & 48.197 & 353 & .137 & - & - \\
Within Groups & 48.451 & 355 & - & - & - \\
Total & \multicolumn{3}{|c}{}
\end{tabular}

Tabel 10. Group Statistics

\begin{tabular}{|ll|c|c|c|c|}
\hline & Tempat Tumbuh & $\mathbf{N}$ & Mean & $\begin{array}{c}\text { Std. } \\
\text { Deviation }\end{array}$ & $\begin{array}{c}\text { Std. error } \\
\text { Mean }\end{array}$ \\
\hline Total & Perkotaan & 332 & 3.1387 & .27915 & .01532 \\
& Pedesaan & 24 & 3.3083 & .26156 & .05339 \\
Akidah & Perkotaan & 332 & 3.5423 & .29205 & .01603 \\
& Pedesaan & 24 & 3.7025 & .20609 & .04207 \\
Ibadah & Perkotaan & 332 & 2.7920 & .38580 & .02117 \\
& Pedesaan & 24 & 2.9275 & .45638 & .09316 \\
& Pedklak & 332 & 3.0806 & .36866 & .02023 \\
& Pedesaan & 24 & 3.2917 & .32760 & .06687 \\
\hline
\end{tabular}


Tabel 11. Independent Sample T Test

\begin{tabular}{|c|c|c|c|c|c|c|c|c|c|c|}
\hline & \multirow{2}{*}{\multicolumn{2}{|c|}{$\begin{array}{l}\text { Levene's Test } \\
\text { for Equality } \\
\text { of Variances }\end{array}$}} & \multicolumn{7}{|c|}{ t-test for Equality of Means } \\
\hline & & & & \multirow[b]{2}{*}{$\mathbf{T}$} & \multirow[b]{2}{*}{ Df } & \multirow[b]{2}{*}{$\begin{array}{c}\text { Sig. } \\
\text { (2-tailed) }\end{array}$} & \multirow[b]{2}{*}{$\begin{array}{c}\text { Mean } \\
\text { Difference }\end{array}$} & \multirow[b]{2}{*}{$\begin{array}{l}\text { Std. Error } \\
\text { Difference }\end{array}$} & \multicolumn{2}{|c|}{$\begin{array}{l}\text { 95\% Confidence } \\
\text { Interval of the } \\
\text { Difference }\end{array}$} \\
\hline & & $\mathbf{F}$ & Sig. & & & & & & Lower & Upper \\
\hline \multirow[t]{2}{*}{ Total } & $\begin{array}{l}\text { Equal variances } \\
\text { assumed }\end{array}$ & .283 & .595 & -2.886 & 354 & .004 & -.16960 & .05877 & -.28518 & -.05401 \\
\hline & $\begin{array}{l}\text { Equal variances } \\
\text { not assumed }\end{array}$ & - & - & -3.053 & 26.931 & .005 & -.16960 & .05555 & -.28358 & -.05561 \\
\hline \multirow[t]{2}{*}{ Akidah } & $\begin{array}{l}\text { Equal variances } \\
\text { assumed }\end{array}$ & 3.488 & .063 & -2.638 & 354 & .009 & -.16018 & .06072 & -.27959 & -.04077 \\
\hline & $\begin{array}{l}\text { Equal variances } \\
\text { not assumed }\end{array}$ & & - & -3.558 & 30.119 & .001 & -.16018 & .04502 & -.25210 & -.06826 \\
\hline \multirow[t]{2}{*}{ Ibadah } & $\begin{array}{l}\text { Equal variances } \\
\text { assumed }\end{array}$ & .948 & .331 & -1.641 & 354 & .102 & -.13554 & .08260 & -.29799 & .02690 \\
\hline & $\begin{array}{l}\text { Equal variances } \\
\text { not assumed }\end{array}$ & - & - & -1.419 & 25.433 & .168 & -.13554 & .09553 & -.33213 & .06104 \\
\hline \multirow[t]{2}{*}{ Akhlak } & $\begin{array}{l}\text { Equal variances } \\
\text { assumed }\end{array}$ & .962 & .327 & -2.728 & 354 & .007 & -.21109 & .07739 & -.36330 & -.05889 \\
\hline & $\begin{array}{l}\text { Equal variances } \\
\text { not assumed }\end{array}$ & - & - & -3.022 & 27.388 & .005 & -.21109 & .06986 & -.35435 & -.06784 \\
\hline
\end{tabular}

\section{KESIMPULAN}

Dalam penelitian ini terungkap bahwa ketiga aspek keislaman (akidah, ibadah dan akhlak) di kalangan mahasiswa UAI angkatan 2008, 2009 dan 2010 tidaklah paralel. Aspek akidah mereka relatif baik dengan prosentase kategori tinggi mencapai $23 \%$ dan yang rendah "hanya" $14,3 \%$. Namun dalam aspek ibadah perbandingannya terbalik, dan semakin memprihatinkan dalam aspek akhlak. Menariknya, dalam aspek akidah, item-item dengan poin rendah justru yang terkait dengan isu-isu aktual.

Di sisi lain, potret keislaman responden berdasarkan fakultas sangat variatif. Ada dugaan faktor yang pengaruhnya paling dominan adalah lingkungan serta didikan dan pengawasan orangtua. Sebab terungkap bahwa realitas keislaman responden yang tumbuh di lingkungan pedesaan lebih baik daripada yang tumbuh di lingkungan perkotaan dengan perbedaan yang signifikan. Ini paralel dengan temuan bahwa responden yang tinggal di asrama, potret keislaman mereka juga lebih baik dibanding responden yang tinggal di rumah (bersama orang tua). Berbeda dengan faktor jender, yang terlihat tidak berpengaruh signifikan terhadap realitas keislaman mereka. Artinya, anggapan remaja puteri lebih alim dari remaja putera, dan atau remaja putera lebih sulit "dikendalikan" daripada remaja puteri, tidak sepenuhnya benar.

Dalam konteks membumikan Islamic values sebagai salah satu TED UAI, penelitian semacam ini perlu diselenggarakan secara kontinyu. Sehingga kebijakan dan pendekatan yang dikembangkan dalam membangun karakter mahasiswa UAI yang berlandaskan nilai-nilai spiritual dan moral Islam bisa lebih akurat karena didasarkan pada sebuah penelitian ilmiah updated. Inilah pengejewantahan dari research based policy yang merupakan spirit penting dalam dunia perguruan tinggi.

Berhubung penelitian ini termasuk "perintis" dalam temanya, alat ukur yang digunakan baru merujuk pada teori-teori keilmuan Islam murni ('Ulum syar'iyyah). Maka dalam penelitian-penelitian serupa yang akan datang perlu dikombinasikan dengan teori-teori keilmuan yang lain -semisal psikologi, sehingga alat ukurnya bisa lebih komprehensif dan mendalam.

Terkait dengan dengan pembumian Islamic values di lingkungan UAI, perlu ada kebijakan dan perhatian lebih terhadap kualitas ibadah para mahasiswa. Karena di ranah ibadah inilah kesenjangan realitas keislaman mereka mulai tampak, yang kemudian semakin terlihat senjang di ranah akhlak. 
Pembumian Islamic values ini harus menjadi concern dan cita-cita semua pihak, termasuk para orang tua mahasiswa; karena nilai-nilai yang ditransfer di UAI tidak akan terpatri dengan baik tanpa dukungan atmosfer yang kondusif di rumah/keluarga.

\section{DAFTAR PUSTAKA}

[1] HD., Kaelany (2000), Islam dan Aspek-aspek Kemasyarakatan.Bumi Aksara: Jakarta

[2] Bungin, Burhan (2005), Metodologi Penelitian Kuantitatif. Kencana Prenada Media Group: Jakarta
[3] Hendropuspito, D. (1983), Sosiologi Agama. Kanisius:Yogyakarta

[4] Esposito, John L. (2010), What Everyone needs to know about Islam. Oxford University Press: New York

[5] Al-Ghazali, Abu Hamid (tt). Al-iqtishad fil i'tiqad. Dar al-Hadith: Cairo

[6] Thohir, Luth (2007), Dakwah dan Pemikirannya. GIP: Jakarta

[7] Hadi, Sutrisno (1990), Metodologi Research. Andi offset: Yogyakarta

[8] Arikunto, Suharsimi (1993), Manajemen Penelitian. Rineka Cipta: Jakarta 